\title{
Estudio experimental sobre la regeneración ósea mandibular de la rata con diferentes biomateriales
}

\author{
Experimental study in rats of mandibular bone regeneration \\ with different biomaterials
}

\author{
B. Peral Cagigal', L.M. Redondo González' ${ }^{1}$ A. Verrier Hernández², A. Serrat Soto', \\ M.Á. Torres Nieto ${ }^{3}$, C. Vaquero Puerta ${ }^{4}$
}

\begin{abstract}
Resumen: Objetivo. Los defectos óseos mandibulares resultantes de infecciones, traumatismos o resecciones oncológicas, van a producir severos problemas funcionales y/o estéticos, que van a precisar de un tratamiento complejo. Durante los últimos años, las aportaciones al terreno de la reconstrucción ósea se han debatido entre métodos tan dispares como la distracción ósea o la utilización de colgajos libres microvascularizados, pasando por un sin fin de biomateriales. El objetivo de este estudio fue comparar la formación de hueso nuevo tras la aplicación de una membrana reabsorbible y dos tipos de sustitutivos óseos. Material y método. Se utilizaron 24 ratas adultas macho tipo Wistar, en las que se crearon defectos circulares de $4 \mathrm{~mm}$ de diámetro en ambos lados de la mandíbula. Se formaron 4 grupos, un grupo control y 3 grupos experimentales. Los animales fueron sacrificados a las 3 y 6 semanas de la cirugía, realizándose un análisis radiológico e histológico. Resultados. Los defectos control no mostraron formación ósea, apareciendo una reparación por tejido fibroso. La membrana de hueso utilizada de forma aislada, actuó como una barrera eficaz excluyendo los tejidos no osteogénicos, pero no se produjo reparación total del defecto en ningún caso. El grupo de Colloss ${ }^{\circledR}$ y membrana, mostró una regeneración ósea completa del defecto a las 6 semanas. El grupo de NovaBone ${ }^{\circledR}$ y membrana, no mostró formación ósea, apareciendo las partículas del biomaterial ocupando el defecto. Conclusiones. La regeneración ósea fue significativamente mayor en los defectos rellenos con Colloss ${ }^{\circledR}$ y cubiertos con la membrana de Lambone ${ }^{\circledR}$, comparado con los otros grupos experimentales.
\end{abstract}

Palabras clave: Regeneración ósea guiada; Sustitutivos óseos; Membrana de hueso desmineralizado; Colágeno liofilizado bovino; Vidrio bioactivo

Recibido: 11.04 .2008

Aceptado: 15.10 .2008

1 Médico Adjunto. Servicio de Cirugía Oral y Maxilofacial. Hospital del Río Hortega de Valladolid. España

2 Jefe de Servicio. Cirugía Oral y Maxilofacial. Hospital del Río Hortega de Valladolid. España

3 Médico Adjunto. Servicio de Anatomía Patológica. Hospital del Río Hortega de Valladolid. España

4 Jefe de Servicio. Angiología y Cirugía Vascular. Hospital Clínico de Valladolid. Catedrático del Departamento de Cirugía. Director del Laboratorio de Investigación Quirúrgica y Técnicas Experimentales. Facultad de Medicina de Valladolid. España
Abstract: Objective. Mandibular bone defects can occur as a result of trauma, neoplasm, or infectious conditions. Such conditions often are associated with severe funtional and esthetic problems. Corrective treatment often is complicated by limitations in tissue adaptation. The aim of this study was to compare new bone formation following application of a bioabsorbable membrane and two types of bone substitutes. Material and method. In the present study, 24 fourmonth-old male Wistar rats were used. Standardized round throughand-through bone defects (4 $\mathrm{mm}$ in diameter) were made in both mandibles and the rats were divided into four groups: one control group and 3 experimental groups. Animals were killed 3 and 6 weeks after surgery. Bone defect healing was assessed by radiologic and histologic analysis. Results. The control defects showed no bone formation; holes were filled with fibrous connective tissue. Bone membrane alone was an efficient barrier, excluding nonosteogenic tissue. However, new bone formation underneath the membrane was incomplete. The Colloss ${ }^{\circledR}+$ membrane group showed complete healing after 6 weeks. The NovaBone ${ }^{\circledR}+$ membrane group showed no bone formation and particles appeared in the defect. Conclusions. The percentage bone regeneration was significantly better in the defects filled with Colloss ${ }^{\circledR}$ and covered with Lambone ${ }^{\circledast}$ than the other experimental groups.

Key words: Guided bone regeneration; Bone substitutes; Demineralized laminar bone membrane; Bovine bone collagenprotein extracts; Bioactive glass.

\section{Correspondencia:}

Dra. Beatriz Peral Cagigal

Servicio Regional de Cirugía Oral y Maxilofacial

Hospital Universitario del Río Hortega

$\mathrm{C} /$ Cardenal Torquemada s/n

47010 Valladolid, España

E-mail: beaperal77@yahoo.es 


\section{Introducción}

En el terreno de la cirugía oral y maxilofacial a menudo nos encontramos con defectos óseos provocados por diferentes causas (traumatismos, tumores, etc.), que constituyen un reto terapéutico debido a que precisan una reconstrucción que garantice un adecuado resultado estético y funcional.

El hueso córtico-esponjoso autólogo representa el material reconstructivo ideal, pues aporta biocompatibilidad total, tiene un elevado potencial osteogénico, una gran resistencia mecánica y a la infección, y asegura una rápida consolidación. ${ }^{1}$ El objetivo consiste en hallar un sustitutivo del hueso autólogo, ya sea biológico o sintético, que permita reparar los defectos óseos sin los inconvenientes de la morbilidad del sitio donante y de las limitaciones en cuanto a la cantidad a obtener y a la morfología anatómica del mismo. Así, en nuestro estudio experimental, sugerimos que el potencial de regeneración ósea mediante membranas puede ser incrementado al asociar un material de relleno del defecto, ya que evita el colapso de la membrana, aumenta la concentración de factores osteogénicos en el defecto, y define el contorno anatómico del hueso neoformado.

La regeneración ósea guiada (ROG) se fundamenta en la utilización de sistemas barrera mediante membranas que aislan una determinado defecto óseo, con la intención de evitar el crecimiento de tejidos con capacidad de reparación rápida, como el tejido conectivo, que interfieren con el potencial osteogénico del defecto.

La membrana utilizada en nuestro estudio es una lámina de hueso desmineralizado de cadáver humano (Lambone ${ }^{\circledR}$, Pacific Coast Tissue Bank, L.A., CA, EE.UU.), radiolúcida, biocompatible, y que se reabsorbe en 6-8 meses, y que presenta capacidad osteoinductiva y osteoconductiva.

El NovaBone-C/M ${ }^{\otimes}$ (Porex Surgical, Inc., Newnan, GA, EE.UU.) es un vidrio bioactivo sintético, osteoconductivo, biocompatible, antimicrobiano, radiolúcido, que se reabsorbe por disolución en 69 meses. Esta cerámica se une al hueso por fijación bioactiva, a través de la formación de una capa de hidroxicarbonatoapatita que es equivalente, química y estructuralmente, a la fase mineral del hueso. ${ }^{2}$

El Colloss ${ }^{\circledR}$ (Ossacur ${ }^{\circledR}$ Medical Products, Alemania) es un preparado a base de extracto de matriz ósea bovina de la diáfisis, que contiene principalmente colágeno tipo I y proteínas insolubles. Este colágeno liofilizado posee actividad osteoinductiva, es biocompatible, radiolúcido y se reabsorbe en 6-8 semanas.

\section{Material y método}

\section{Modelo experimental y diseño del estudio}

Se utilizaron 24 ratas blancas machos de raza Wistar, de 3-4 meses de edad (adultas). Los animales fueron distribuidos en 4 grupos, según el tipo de biomaterial de relleno y membrana utilizados (Tabla 1).

Los animales fueron anestesiados mediante una inyección intraperitoneal de ketamina ( $80 \mathrm{mg} / \mathrm{kg}$ de peso), y posteriormente se infiltró localmente con articaína (Ultracaín ${ }^{\circledR}, 0,5 \mathrm{ml}$ sin vasoconstrictor). A través de un abordaje submandibular se accedió al ángulo y rama ascendente mandibular donde se realizó un defecto óseo circular de

\section{Introduction}

In oral and maxillofacial surgery, we often have to deal with bone defects of different origins (trauma, tumors, and other) that constitute a therapeutic challenge because reconstruction must guarantee acceptable aesthetic and functional results.

Autologous cortical-cancellous bone is the ideal reconstructive material because it is completely biocompatible, has good osteogenic potential, mechanical resistance and resistance to infection, and ensures rapid consolidation. ${ }^{1}$ The objective is to find a biological or synthetic substitute for autologous bone that allows bone defects to be repaired without the disadvantages of donor-site morbidity, limitations in the amount of bone that can be obtained, and the anatomic morphology of the bone. In the present experimental study, we hypothesized that the potential of membranes to induce bone regeneration can be increased by using filler in the defect, as the filler impedes membrane collapse, increases the concentration of osteogenic factors in the defect, and defines the anatomic contours of the neoformed bone.

Guided bone regeneration (GBR) uses membrane barrier systems to isolate the bone defect, in order to impede the growth of tissues with rapid repair capacity, such as connective tissue, which interfere with the osteogenic potential of the defect.

The membrane used in our study was sheets of demineralized cadaveric cortical bone (Lambone ${ }^{\circledR}$, Pacific Coast Tissue Bank, Los Angeles, CA, USA), which is radiotransparent, biocompatible, and resorbed in 6-8 months. This membrane has osteoinductive and osteoconductive capacity.

NovaBone- $C / M^{\circledast}$ (Porex Surgical, Inc., Newnan, GA, USA) is a synthetic, bioactive, osteoconductive, biocompatible, antimicrobial, radiotransparent glass that is resorbed by dissolution in 6-9 months. This ceramic binds to bone by bioactive fixation, forming a hydroxycarbonate apatite layer that is chemically and structurally equivalent to the mineral phase of bone.

Colloss $^{\circledR}$ (Ossacur ${ }^{\circledR}$ Medical Products, Germany) is a preparation based on bovine diaphyseal bone matrix extract, which contains mainly collagen type I and insoluble proteins. This freeze-dried collagen has osteoinductive activity, is biocompatible and radiotransparent, and resorbs in 6 to 8 weeks.

\section{Material and Method}

Experimental model and study design

Twenty-four white male Wistar rats were used, age 34 months (adult). The animals were distributed into 4 groups according to the type of biomaterial filler and membrane used (Table 1).

The animals were anesthetized using an intraperitoneal injection of ketamine ( $80 \mathrm{mg} / \mathrm{Kg}$ weight), followed by local 
Tabla 1. Distribución por grupos y subgrupos de los animales

\begin{tabular}{|c|c|c|c|c|}
\hline Grupo & Subgrupo & Sustitutivo óseo & Membrana (Lambone ${ }^{\circledR}$ ) & Sacrificio \\
\hline Grupo I & $\begin{array}{l}A(n=6) \\
B(n=6)\end{array}$ & $\begin{array}{l}\text { No } \\
\text { No }\end{array}$ & $\begin{array}{l}\text { No } \\
\text { No }\end{array}$ & $\begin{array}{l}3^{\mathrm{a}} \text { semana } \\
6^{\mathrm{a}} \text { semana }\end{array}$ \\
\hline Grupo II & $\begin{array}{l}A(n=6) \\
B(n=6)\end{array}$ & $\begin{array}{l}\text { No } \\
\text { No }\end{array}$ & $\begin{array}{l}\text { Sí } \\
\text { Sí }\end{array}$ & $\begin{array}{l}3^{\mathrm{a}} \text { semana } \\
6^{\mathrm{a}} \text { semana }\end{array}$ \\
\hline Grupo III & $\begin{array}{l}A(n=6) \\
B(n=6)\end{array}$ & $\begin{array}{l}\text { Colloss }^{\circledR} \\
\text { Colloss }^{\circledR}\end{array}$ & $\begin{array}{l}\text { Sí } \\
\text { Sí }\end{array}$ & $\begin{array}{l}3^{\mathrm{a}} \text { semana } \\
6^{\mathrm{a}} \text { semana }\end{array}$ \\
\hline Grupo IV & $\begin{array}{l}A(n=6) \\
B(n=6)\end{array}$ & $\begin{array}{l}\text { NovaBone }{ }^{\circledR} \\
\text { NovaBone }^{\circledR}\end{array}$ & $\begin{array}{l}\text { Sí } \\
\text { Sí }\end{array}$ & $\begin{array}{l}3^{\mathrm{a}} \text { semana } \\
6^{\mathrm{a}} \text { semana }\end{array}$ \\
\hline
\end{tabular}

Table 1. Distribution of animals by groups and subgroups

$\begin{array}{lcccc}\text { Group } & \text { Subgroup } & \text { Bone substitute } & \left.\text { Membrane (Lambone }{ }^{\circledR}\right) & \text { Sacrifice } \\ \text { Group I } & A(n=6) & \text { No } & \text { No } & \text { Week 3 } \\ & B(n=6) & \text { No } & \text { No } & \text { Week 6 } \\ \text { Group II } & A(n=6) & \text { No } & \text { Yeek 3 } \\ & B(n=6) & \text { No } & \text { Yes } & \text { Week 6 } \\ \text { Group III } & A(n=6) & \text { Colloss } & \text { Yes } & \text { Week 3 } \\ & B(n=6) & \text { Colloss } & \text { Week 6 } \\ \text { Group IV } & A(n=6) & \text { NovaBone } & \text { Yes } & \text { Week 3 } \\ & B(n=6) & \text { NovaBone } & \text { Week 6 }\end{array}$

$4 \mathrm{~mm}$ de diámetro (defecto de tamaño crítico) (Fig. 1). La ostectomía fue realizada con un motor eléctrico mediante una fresa de carbono de 4 $\mathrm{mm}$, y bajo irrigación continua con suero fisiológico. El experimento se realizó de forma bilateral.

En el grupo control (I) el defecto se dejó vacío y sin cubrir. En el grupo II, los defectos se cubrieron, por vestibular y por lingual, con una membrana de hueso desmineralizado $\left(\right.$ Lambone $^{\circledR}$ ), de $5 \mathrm{~mm}$ de lado. En el grupo III, los defectos se rellenaron con colágeno liofilizado (Colloss ${ }^{\circledR}$ ) y fueron cubiertos con Lambone ${ }^{\circledR}$. En el grupo IV, los defectos se rellenaron

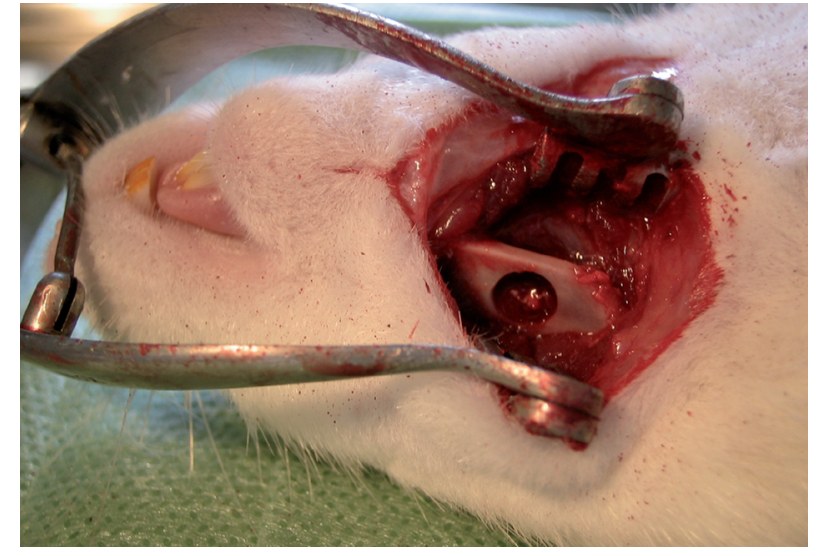

Figura 1. Imagen intraoperatoria del defecto circular mandibular de tamaño crítico.

Figure 1. Intraoperative image of the critically sized mandibular circular defect. infiltration of articaine (Ultracaine $^{\circledR} 0.5 \mathrm{ml}$ without vasoconstrictor). A submandibular approach was used to expose the mandibular angle and ramus, where a circular bone defect 4 $\mathrm{mm}$ in diameter was made (a critically sized defect) (Fig. 1). The ostectomy was performed with an electrical motor and a 4-mm carbon burr under continuous irrigation with physiologic serum. The experiment was bilateral.

The defect was left open and uncovered in the control group (group I). In group II, the defects were covered on the vestibular and lingual side with demineralized bone membrane (Lambone ${ }^{\circledR}$ ) measuring $5 \mathrm{~mm}$ on the side. In group III, the defects were filled with freeze-dried collagen (Colloss ${ }^{\circledR}$ ) and covered with Lambone ${ }^{\circledR}$. In group IV, the defects were filled with bioactive glass (NovaBone ${ }^{\circledR}$ ) and covered with Lambone ${ }^{\circledR}$.

A series of parameters were evaluated in the postoperative clinical follow-up: general condition of animal, appearance of the wound and intervention zone, bleeding, exudates or collections, extrusion of biomaterials or membranes, 
La obtención de las muestras se realizó mediante extirpación en bloque de cada una de las hemimandíbulas, obteniéndose un total de 48 muestras. Posteriormente, se realizó la valoración macroscópica, seguida de inmersión en formol al 10\% tamponado, para ulterior procesamiento radiológico e histológico.

Cada muestra fue radiografiada utilizando un equipo radiológico dental Trophy CCX digital, siendo todas las radiografías sometidas a las mismas condiciones de exposición. Cada muestra apoyada sobre su superficie lingual fue colocada sobre la placa radiológica dental (Fig. 2). Junto a ella se colocó una lámina escalonada de aluminio (Al), con un total de 6 escalones, correspondien-

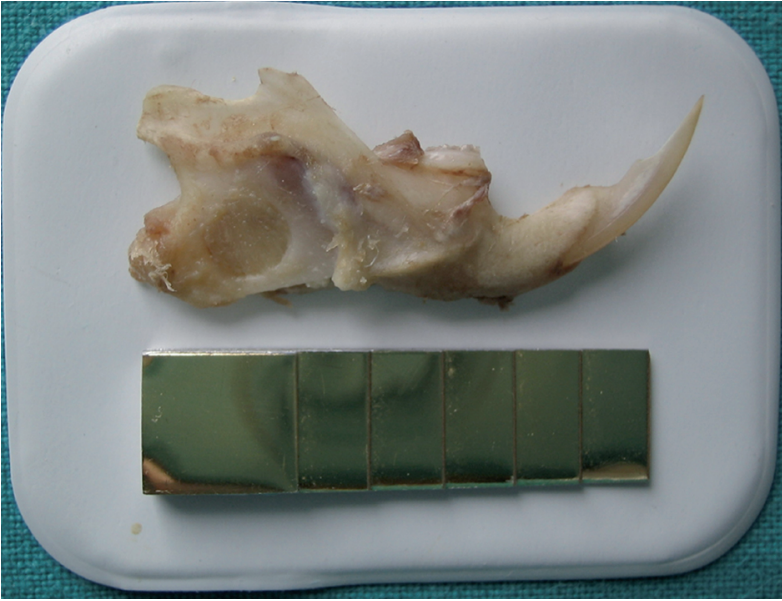

Figura 2. Hemimandíbula sobre la placa radiológica dental, y junto a la lámina escalonada de aluminio.

Figure 2. Mandible positioned on a dental radiologic plate, next to an aluminum scale. and degenerative changes caused by dental injuries. Once the experimental period concluded, the animals were killed by injecting an intraperitoneal anesthetic overdose of ketamine (Ketolar $\left.{ }^{\circledR}\right)$.

Specimens were obtained by block excision of each of mandible. A total of 48 specimens was obtained. A macroscopic evaluation was made and then the piece was immersed in buffered formolin $10 \%$ for radiologic and histologic processing. Each specimen was radiographed using Trophy CCX do a cada escalón un incremento del grosor de $1 / 3$ de $\mathrm{mm}$ de Al. De esta manera, la escala se extendía desde $0,33 \mathrm{~mm}$ hasta $2 \mathrm{~mm}$ de Al.

En cada hemimandíbula se talló un bloque óseo cuadrado que incluía el defecto óseo a estudio con un margen óseo mandibular (cuadrados de $7 \mathrm{~mm}$ de lado). Los bloques óseos se sumergieron en una solución descalcificante de ácido fórmico, y fueron procesados, incluidos en parafina, tallados mediante un microtomo de rotación, y finalmente teñidos mediante hematoxilina-eosina.

\section{Variables de estudio}

Valoración macroscópica. En el momento del sacrificio y disección de las muestras se realizó una valoración descriptiva de los siguientes parámetros: a) organización anatómica y tisular, b) infecciones, exudados o colecciones hísticas; c) desplazamiento del lecho de los biomateriales; d) presencia de fracturas; e) cambios degenerativos dentarios; f) secuestros óseos; g) consistencia y forma superficial del defecto.

Valoración radiológica. Se realizó un estudio densitométrico de la reparación radiológica del defecto mandibular. Las imágenes radiológicas fueron transferidas a un ordenador y digitalizadas según niveles de grises (256 niveles), utilizando un programa informático de Análisis de Imagen Sigma Scan Pro 5.0 para Windows. El área de estudio fue definida como un área circular de $4 \mathrm{~mm}$ de diámetro, similar al defecto quirúrgico original. El valor de la densidad óptica del área de estudio fue expresado en relación al valor de los escalones de la lámina de Al, previamente determinados. De esta manera, la densidad del defecto mandibular fue expresada en equivalentes a tercios de $\mathrm{mm}$ de $\mathrm{Al}$, dando un valor entre 0 y 6 .

Valoración histológica. Para la lectura histológica de las preparaciones se utilizó un microscopio óptico Olympus BX41 adaptado a una cámara digital Olympus DP70, y conectado a un ordenador para la recogida de imágenes. Para el análisis de los datos histológicos en los grupos de estudio, nos basamos en 4 parámetros siguiendo la escala de puntuación numérica asignada a cada uno de ellos, según el modelo propuesto por Heiple (Tabla 2). ${ }^{3}$ digital dental radiologic equipment. All radiographs were made under the same exposure conditions. Each specimen was laid on its lingual surface and placed on the dental radiof 6 grades, each of which corresponded to an increase in thickness of $1 / 3 \mathrm{~mm} \mathrm{Al}$, was placed next to the mandible. The range of the scale was $0.33 \mathrm{~mm}$ to $2 \mathrm{~mm} \mathrm{Al}$.

A square block of bone was excised from each mandible, which included the bone defect to be studied and a margin of mandibular bone (cube with a $7 \mathrm{~mm}$ side). The bone blocks were submerged in a decalcifying solution of formic acid and processed, embedded in paraffin, sliced with a rotation microtome, and finally stained with hematoxylin-eosin.

\section{Study variables}

Macroscopic evaluation: At the time of death of the rat and dissection of the specimens, a descriptive evaluation was made of the following parameters: a) anatomic and tissue organization; b) infections, exudates or tissue collections; c) biomaterial displacement; d) presence of fractures; e) dental degenerative changes; $f$ ) bone sequestration; and g) consistency and superficial form of the defect.

Radiologic evaluation: A densitometric study was made of the radiologic repair of the mandibular defect. The radiologic images were transferred to a computer and digitalized according to a gray scale (256 levels), using the Sigma Scan Pro Image Analysis 5.0 for Windows computer program. The study area was defined as a circular cylinder 4 $\mathrm{mm}$ in diameter, similar to the original surgical defect. The optical density of the study area was expressed in relation to the Al grades described above. The density of the mandibular defect was expressed as an equivalent to one-third millimeter of Al, resulting in a value from 0 to 6 .

Histologic evaluation: The histologic reading of the preparations was made with an Olympus BX41 optical microscope adapted to an Olympus DP70 digital camera, which ographic plate (Fig. 2). An aluminum (Al) plate with a total 
Análisis estadístico: Se realizó mediante el programa informático estadístico SPSS para Windows. Cada parámetro fue estudiado según descriptores estadísticos básicos, utilizando medidas de tendencia central y de dispersión. En los test estadísticos usados para contrastar hipótesis el nivel de significación estadística elegido fue el 5\%.

\section{Resultados}

Valoración clínica postoperatoria: El estado general de los animales fue satisfactorio en todos los grupos; observándose tan sólo una tumefacción de partes blandas debido a la ostectomía, que desapareció en 24-48 horas sin tratamiento.

Resultados macroscópicos: Se rechazaron 2 muestras del estudio (por absceso $y$ fractura mandibular). Los resultados se refieren a las 46 hemimandíbulas restantes.

En el grupo control, se produjo una ocupación del defecto por tejido blando. En los grupos experimentales no se observó desplazamiento de los sustitutivos óseos ni de las membranas, las cuales fueron identificadas tanto a las 3 como a las 6 semanas, mostrando una leve reabsorción periférica, pero sin desplazamientos en relación al defecto y con buena adhesión e integración al hueso mandibular.

Resultados radiológicos descriptivos: Grupo I (grupo control): Tanto a la $3^{\mathrm{a}}$ como a la $6^{a}$ semana, se encontraron mínimos signos de reparación radiológica, siendo la norma hallar defectos mandibulares circulares radiotransparentes (Fig. 3A).

Grupo II (membrana de Lambone ${ }^{\circledR}$ ): A las 3 semanas de evolución mostró bajos niveles de radiopacidad a nivel del defecto, con conservación de la forma circular del mismo. A las 6 semanas, la radioopacidad aumentó mostrando signos de reparación ósea con un crecimiento centrípeto desde los rebordes del defecto (Fig. 4A).

Grupo III (membrana de Lambone ${ }^{\circledR}$ y (Colloss ${ }^{\circledast}$ ): A la $3^{\text {a }}$ semana ya mostraba niveles de radiopacidad homogéneos en el centro del defecto, aunque la continuidad en el reborde todavía no era muy relevante. A las 6 semanas, la reparación radiológica de los defectos era prácticamente total en todos ellos (80-100\%), mostrando una ele-
Tabla 2. Escala de puntuación numérica asignada a cada uno de los parámetros histológicos, siguiendo el modelo propuesto por Heiple $^{3}$

\section{Grado de madurez ósea}

0 . Ausente.

1. Presencia de células indiferenciadas.

2. Proliferación y diferenciación de las células indiferenciadas a células formadoras de hueso.

3. Presencia de islotes aislados de hueso inmaduro.

4. Espículas óseas uniendo los islotes de hueso inmaduro conformando un patrón heterogéneo.

5. Hueso maduro compacto.

Presencia y calidad de médula ósea

0 . Ausente.

1. Hematopoyéticamente activa, presencia mayoritaria de eritrocitos.

2. Disminución del número de eritrocitos y aumenta el de adipocitos.

3. Médula ósea amarilla.

Continuidad del defecto-hueso normal (unión ósea)

0 . Ausencia de formación ósea en el reborde del defecto.

1. Escasa formación ósea.

2. Moderada formación ósea; $2 / 3$ del defecto sin relleno óseo.

3. Elevada formación ósea; $1 / 3$ del defecto sin relleno óseo.

4. Relleno casi total del defecto (mayor de $2 / 3$ del defecto).

5. Continuidad del defecto con el hueso normal del $100 \%$.

Formación ósea periférica

0 . Ausente.

1. Escasa.

2. Moderada.

3. Elevada.

Tabla 2. Scale of numerical scores assigned to each histologic parameter, following the model proposed by Heiple 3

\section{Bone maturity grade}

0 . Absent.

1. Presence of undifferentiated cells.

2. Proliferation and differentiation of undifferentiated cells into bone-forming cells.

3. Presence of isolated islets of immature bone.

4. Bone spicles linking islets of immature bone in a heterogeneous pattern.

5. Compact mature bone.

Presence and quality of bone marrow

0 . Absent.

1. Hematopoietically active, majority presence of erythrocytes.

2. Reduced number of erythrocytes and increased number of adipocytes.

3. Yellow bone marrow.

Defecto-normal bone continuity (bone junction)

0 . Absence of bone formation on the edge of the defect.

1. Scant bone formation.

2. Moderate bone formation; no bone filling in $2 / 3$ of defect.

3. High bone formation; no bone filling in $1 / 3$ of defect.

4. Almost total bone defect filling (more than $2 / 3$ of the defect).

5. Continuity of defect with normal bone, $100 \%$.

\section{Peripheral bone formation}

0 . Absent.

1. Scant.

2. Moderate

3. High. was connected to a computer for recording the images. The histologic data in the study groups were analyzed using four parameters according to a scale of numerical scores assigned to each parameter, according to the model proposed by Heiple (Table 2). ${ }^{3}$

Statistical analysis: SPSS for Windows was the statistical program used. Each parameter was studied according to the basic statistical descriptors and using central tendency and dispersion measures. In the statistical test used to compare hypotheses, the level of statistical significance was $5 \%$.

\section{Results}

Postoperative clinical evaluation: The general condition of the animals was satisfactory in all the groups. Only soft-tissue swelling due to ostectomy was observed, which disappeared in 24-48 hours without treatment.

Macroscopic results: Two study specimens were discarded (due to abscess and mandibular fracture). The results refer to the 46 remaining mandibles.

In the control group, softtissue occupation of the defect occurred. In the experimental groups, no displacement of the bone substitutes or membranes was observed, which were examined at 3 weeks and 6 weeks. Mild peripheral resorption occurred, but no displacement in relation to the defect. Adherence and integration into 
vada continuidad con los rebordes óseos, y con una distribución muy homogénea de la densidad radiológica (Fig. 5A).

Grupo IV (membrana de Lambone ${ }^{\circledR}$ y NovaBone- $\left(M^{\circledR}\right)$ : A las 3 semanas la radiopacidad de la lesión era muy heterogénea, con un aspecto "granulado" en el centro del defecto. A las 6 semanas, la radiopacidad era mayor y más homogénea, aunque persistía ese aspecto granulado en la reparación radiológica y una falta de continuidad con el reborde óseo del defecto (Fig. 6A).

Resultados radiológicos cuantitativos: La densitometría ósea mostró diferencias estadísticamente significativas $(p<0,001)$ a las seis semanas de evolución, de todos los grupos experimentales (II, III y IV) respecto al grupo control (I), siendo el grupo III (membrana + Colloss ${ }^{\circledR}$ ) el que obtuvo una media más alta $(4,89 \pm 0,66)$.

Resultados histológicos descriptivos:

Grupo I (grupo control): La reparación del defecto se llevó a cabo por tejido blando (fundamentalmente tejido conectivo, muscular y grasa), sin núcleos de osificación y sin presencia de tejido óseo (Fig. 3B).

Grupo II (membrana de Lambone ${ }^{\circledR}$ ): Se observan dos frentes de crecimiento óseo que parten desde los extremos, teniendo como guía a las membranas que permanecen estables delimitando el área del defecto, con íntima adhesión al hueso en sus extremos y no colapsadas. A las 3 semanas la regeneración ósea ocupaba aproximadamente un tercio del defecto, mientras que a las 6 semanas se extendía hasta la mitad del defecto (Fig. 4B); sin embargo, en ningún animal se observó una sustitución ósea completa.

Grupo III (membrana de Lambone ${ }^{\circledR}$ y Colloss ${ }^{\circledR}$ ): A las 3 semanas, podía observarse un defecto mandibular perfectamente delimitado por las membranas, con una importante reparación por un tejido óseo inmaduro de tipo trabeculado, que ocupaba unos 2/3 del mismo pero con cierta falta de continuidad a nivel central. A las 6 semanas, el hueso era más compacto, voluminoso y maduro, mostrando continuidad con los extremos mandibulares, ajustándose al volumen total del defecto y a la forma delimitada por las membranas (Fig. 5B). En ningún caso se detectó la presencia del colágeno bovino.

Grupo IV (membrana de Lambone+ y NovaBone ${ }^{\circledR}$ ): Tanto a las 3 como a las 6 semanas, aparecía un defecto delimitado por las membranas con ausencia de formación ósea, con formación de tejido conjuntivo, con intensa celularidad inflamatoria a cuerpo extraño con abundantes polimorfonucleares alrededor de las partículas del biomaterial (NovaBone ${ }^{\circledR}$ ), que aparecen como gránulos transparentes y birrefringentes (Fig. 6B).

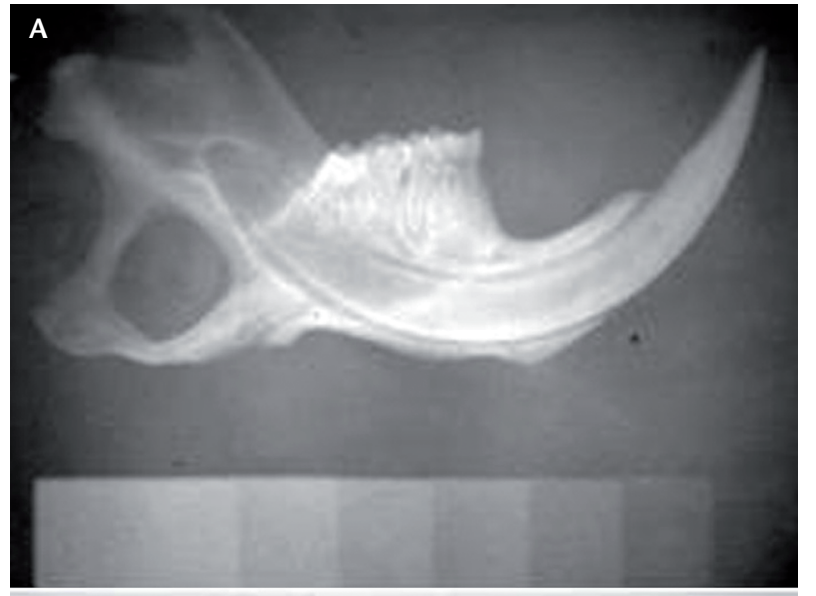

the mandibular bone were good.

Descriptive radiologic results Group I (control group): At both week 3 and week 6, minimum signs of radiologic repair were found; generally, mandibular radiotransparent circular defects were observed (Fig. 3A).

Group II (Lambone ${ }^{\circledR}$ membrane): At 3 weeks of evolution, low levels of radiopacity were observed in the defect, although the circular form of the defect was conserved. At 6 weeks, the radiopacity increased and signs of bone repair with centripetal growth from the edges of the defect was evident (Fig. 4A).

Group III (Lambone ${ }^{\circledR}$ membrane and Colloss $\left.{ }^{\circledR}\right)$ : At 3 weeks, homogeneous levels of radiopacity were evident in the center of the defect, although the continuity around the edge still was not very marked. At 6 weeks, the radiologic repair of the defects was practically complete in every case (80$100 \%)$, showing strong continuity with the surrounding bone and a highly homogeneous distribution of the radiologic density (Fig. 5A).

Group III (Lambone ${ }^{\circledR}$ membrane and NovaBone-C/M ${ }^{\circledR}$ ): At 3 weeks, the radiopacity of the lesion was very heterogeneous, with a "granulated" appearance at the center of the defect. At 6 weeks, the radiopacity was more intense and more homogeneous, although the granular aspect of the radiologic repair and lack of continuity with the bone surrounding the defect persisted (Fig. 6A).

Quantitative radiologic results: Bone densitometry showed statistically significant differences $(p<0.001)$ at 6 weeks of evolution in all the experimental groups (II, III and IV) with respect to the control group (I). Group III (membrane + Colloss $($ ) $)$ achieved the highest mean value $(4.89 \pm 0.66)$.

Descriptive histologic results: Group I (control group): The defect healed at the expense of soft tissue (fundamentally connective, muscular, and adipose tissue). No ossification nuclei or bone tissue were present (Fig. 3B).

Group II (Lambone ${ }^{\circledR}$ membrane): Two fronts of bone growth were observed that started from the ends. Bone 
Resultados histológicos cualitativos: en la Tabla 3 se muestran los valores medios de los puntos obtenidos en los diferentes grupos de tratamiento, siguiendo la escala de puntuación propuesta por Heiple. ${ }^{3}$

Grado de madurez ósea: A las 3 y 6 semanas de evolución, aparecen diferencias significativas $(p<0,01)$ en los grupos II y III con respecto al grupo control (I) y al grupo IV; así como del grupo III con el grupo II.

Presencia y calidad de médula ósea: Tanto a las 3 como a las 6 semanas, aparecen diferencias significativas $(p<0,01)$ del grupo III con respecto a los grupos I, II y IV.

Unión ósea: A las 3 semanas existen diferencias significativas $(p<0,01)$ del grupo III con respecto al grupo control (I), grupo II y grupo IV. A las 6 semanas de evolución además aparecen diferencias $(p<0,05)$ del grupo II respecto al grupo control.

Formación periférica: A las 3 y 6 semanas de evolución, aparecen diferencias significativas $(p<0,05)$ del grupo III con respecto al grupo control (I).

\section{Discusión y conclusiones}

\section{Clínicos y macroscópicos}

Los animales aceptaron el procedimiento quirúrgico sin complicaciones. Tanto los sustitutivos óseos como las membranas fueron considerados biocompatibles y de buena tolerancia desde el punto de vista clínico, ya que no tuvieron problemas en relación a su comportamiento biológico. Las membranas implantadas, solas o asociadas a un sustitutivo óseo, mostraron una buena adherencia a la superficie, con una adecuada integración, sin desplazamientos y sin tendencia al colapso.

\section{Radiológicos e histológicos}

La ausencia de reparación ósea en todos los defectos mandibulares del grupo control, tanto a nivel radiológico como histológico, indica que este modelo experimental es válido para nuestro estudio, por no poseer capacidad autorregenerativa.

Grupo II (membrana de Lambone ${ }^{\circledR}$ ): El empleo de forma aislada de membranas de hueso desmineralizado, mejoró significativamente la regeneración ósea del defecto mandibular, tanto a las 3 como a las 6 semanas, comparada con el grupo control.

En el estudio radiológico esta diferencia sólo fue significativa a las 6 semanas, posiblemente debido a que histológicamente se cons-

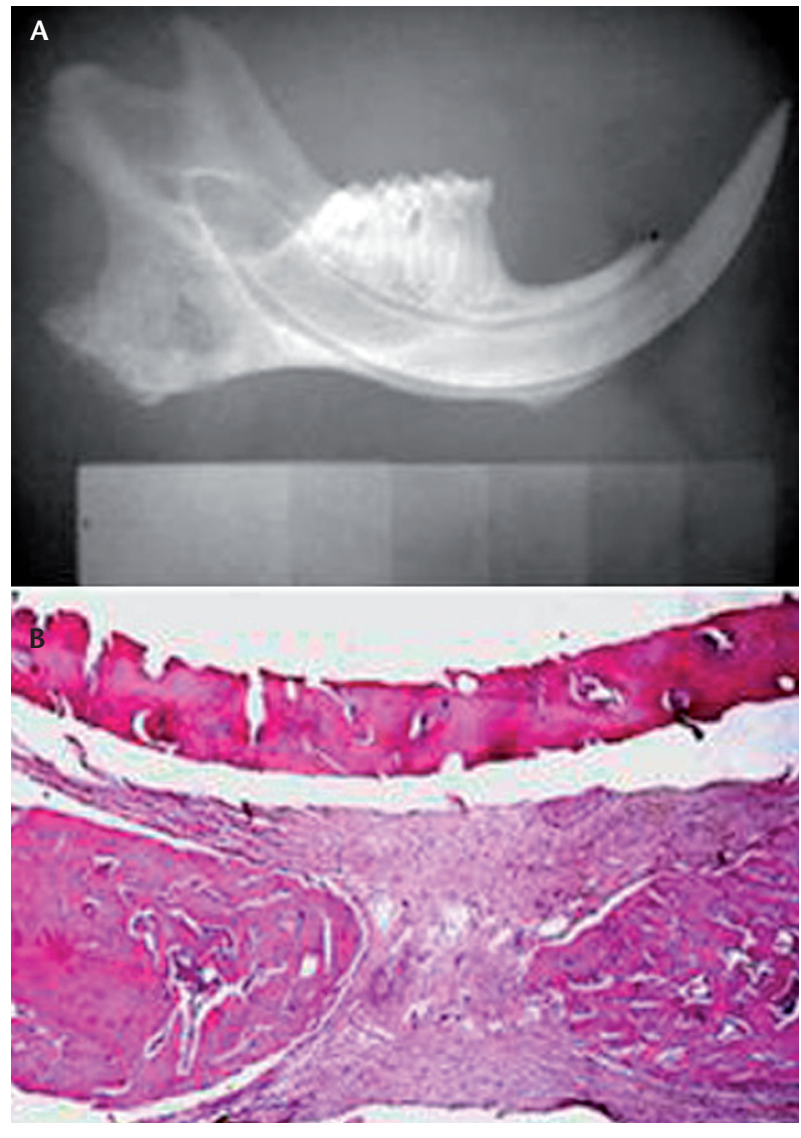

growth was guided by the membranes, which remained stable, delimiting the area of the defect, and intimately adhered to the bone at each end and no collapse. At 3 weeks, bone regeneration occupied approximately one third of the defect, whereas at 6 weeks it extended to the middle of the defect (Fig. 4B). However, complete bone substitution was not observed in any animal.

Group III (Lambone ${ }^{\circledR}$ membrane and Colloss ${ }^{\circledR}$ ): At 3 weeks, a mandibular defect was observed that was perfectly delimited by membranes, with extensive repair by immature cancellous bone tissue that occupied about two thirds of the defect, but with a certain lack of continuity at the central level. At 6 weeks, the bone was more compact, voluminous and mature, showing continuity at the mandibular ends. It filled the total volume of the defect and the space delimited by the membranes (Fig. 5B). In no case was bovine collagen detected.

Group IV (Lambone ${ }^{\circledR}$ membrane and NovaBone ${ }^{\circledR}$ ): At 3 weeks and at 6 weeks, a membrane-delimited defect was observed in which bone formation was absent and connective tissue formation, intense foreign-body inflammatory cellularity, and abundant polymorphonuclear cells around particles of biomaterial (Nov$\left.a B o n e^{\circledR}\right)$; these particles appeared as transparent, birefringent granules (Fig. 6B).

Qualitative histologic results: In Table 3 are shown the mean values of the points obtained in different treatment groups, according to the scale of scores proposed by Heiple. ${ }^{3}$

Bone maturity grade: At 3 weeks and 6 weeks of evolution, significant differences ( $p<0.01)$ appeared in groups II and III with respect to the control group (group I) and group IV, as well as group III with group II.

Bone marrow presence and quality: At 3 weeks and at 6 weeks, significant differences $(p<0.01)$ were found in group III with respect to groups I, II and IV.

Bone junction: At 3 weeks, significant differences $(p<$ $0.01)$ were observed in group III with respect to the control group (group I), group II, and group IV At 6 weeks of evolution, differences $(p<0.05)$ also were observed in group II with respect to the control group. 
tató la existencia de un tejido óseo inmaduro poco calcificado, que no se registra en el análisis radiológico. En nuestro trabajo, no hemos observado regeneración ósea completa del defecto en ninguno de los animales a las 6 semanas, tan sólo del $50 \%$, lo que coincide con los resultados de otros autores en relación al empleo de estas membranas. ${ }^{4}$

Este tipo de membranas, en concordancia con los trabajos de Hämmerle, ${ }^{5}$ sobre reparación histológica con técnicas de ROG, dieron lugar a una formación ósea mayor en áreas periféricas que centrales; lo que concuerda con los resultados radiológicos, donde la radiopacidad aumenta de forma centrípeta desde los bordes del defecto.

Nuestros resultados coincidieron con las descripciones histológicas clásicas de Urist ${ }^{6}$ de osteoinducción ectópica, en relación al proceso de osificación mediante formación cartilaginosa intermedia de los injertos desmineralizados. ${ }^{7}$ En nuestro estudio y, apoyados por los resultados macroscópicos y radiológicos, pudimos comprobar histológicamente como las membranas actuaron como barrera, impidiendo la invasión y proliferación de tejido blando dentro del defecto y mejorando la cantidad de hueso regenerado con respecto a los controles.

En estudios previos, se ha demostrado que es posible la regeneración ósea de defectos críticos mandibulares en ratas tras 6 semanas, empleando membranas no reabsorbibles de GoreTex ${ }^{\circledR} .8,9$ Creemos que en nuestro caso no se produjo una reparación completa (40-50\%), no debido al colapso de las membranas sino a un proceso regenerativo más lento, lo que llevó al fracaso de la técnica a este nivel.

Grupo III (membrana de Lambone ${ }^{\circledR}$ y Colloss ${ }^{\circledR}$ ): La asociación de membrana y colágeno liofilizado generó un incremento en la regeneración ósea con respecto al uso exclusivo de membranas, mostrando diferencias estadísticamente significativas tanto a las 3 como a las 6 semanas, tanto en el estudio radiológico como histológico, con respecto al grupo control. Estos resultados, al igual que han sugerido otros trabajos, demostraron que es posible potenciar los efectos regenerativos de las membranas biodegradables, cuando se asocian a un biomaterial de relleno del defecto. ${ }^{10,11}$ Además, concuerdan con los resultados de otros autores que postulan que el colágeno liofilizado produce una aceleración de la regeneración ósea en la fase temprana (primeras 2 semanas). ${ }^{12}$ Radiográficamente, a las 3 semanas los defectos aparecían con niveles de radiopacidad homogéneos, aunque con cierta falta de continuidad con el hueso adyacente; sin embargo a las 6 semanas pudi- valid for our study, as it does not have self-regenerating capacity.

Group II (Lambone ${ }^{\circledR}$ membrane): The isolated use of demineralized bone membranes significantly improved the bone regeneration of the mandibular defect at 3 weeks and at 6 weeks, compared with the control group.

In the radiologic study, this difference was significant only at 6 weeks, possibly because the immature, hardly calcified bone tissue observed in the histologic study was not evident on radiologic analysis. In our study, we did not observe complete bone regeneration of the defect in any of the animals at 6 weeks, only $50 \%$ bone regeneration, which coincides with the results of other authors who have used barrier membranes. ${ }^{4}$

This type of membranes, according to the studies of Hämmer 5 on histologic repair with GBR techniques, originates more bone formation in peripheral areas than the central areas. This coincides with the radiologic results, which showed that radiopacity increased centripetally from the edges of the defect. 
mos comprobar una reparación entre el 80 y el $100 \%$ del defecto, con alta homogeneidad y continuidad radiológicas.

Histológicamente, a las 3 semanas la formación de hueso fue mayor en áreas periféricas, sin embargo a las 6 semanas, no existían diferencias entre las diferentes áreas del defecto, indicando una mayor uniformidad en la reparación ósea; incluso con casos de reparación total y homogénea del defecto. Con el uso exclusivo de colágeno liofilizado la formación de hueso se aleja frecuentemente de la zona del defecto, lo que determina que la regeneración ósea no se ajuste a la forma del mismo. ${ }^{13}$ Así, las membranas evitan la dispersión del biomaterial, aumentando la concentración del mismo sobre el defecto, ofreciendo un mayor estímulo osteoinductivo y osteoconductivo, con la ventaja de que son biodegradables y no precisan un $2^{\circ}$ acto quirúrgico para su retirada.

El análisis histológico de las muestras confirmó los resultados radiográficos y macroscópicos, aportando datos nuevos que permiten presumir ventajas en la regeneración de defectos críticos mandibulares del tratamiento combinado de colágeno liofilizado con membranas reabsorbibles de hueso desmineralizado.

Grupo IV (membrana de Lambo$n e^{\circledR}$ y NovaBone- $\left.C / M^{\circledR}\right)$ : La regeneración ósea, desde el punto de vista histológico, con el empleo de membranas y el vidrio bioactivo, no mostró en ningún período evolutivo diferencias significativamente mayores a las del grupo control. Curiosamente, a las 6 semanas, el estudio radiológico si mostró diferencias estadísticamente significativas con el grupo control, lo que podría contradecir los resultados histológicos. No obstante, estos resultados también se han producido en otros trabajos, como el de Dorea ${ }^{14}$ en el que defectos femorales en gatos rellenos con vidrio bioactivo eran regenerados radiológicamente a las 6 semanas pero sin producirse concordancia histológica. Por ello, la radiopacidad por sí sola no debe ser utilizada como único criterio para evaluar la regeneración ósea, debiendo correlacionarse, como ya se ha sugerido, con los hallazgos histológicos. ${ }^{15}$ De hecho el aparente descenso en el tamaño del defecto puede ser causado por la precipitación del gel de sílice y formación de fosfato cálcico en la periferia del defecto, lo que dificulta diferenciarlo radiológicamente del tejido huésped. ${ }^{14}$ Histológicamente, los defectos no fueron regenerados a las 6 semanas sino ocupados por tejido fibroso y
Our results coincided with the classic histologic descriptions by Urist ${ }^{6}$ of ectopic osteoinduction in relation to the process of ossification of demineralized grafts by intermediate cartilage formation. ${ }^{7}$ In our study, in addition to macroscopic and radiologic results, we were able to confirm histologically that the membranes acted as a barrier, impeding soft-tissue invasion and proliferation in the defect and improving the amount of bone regenerated with respect to controls.

In previous studies, it has been demonstrated that bone regeneration in critically sized mandibular defects in rats is possible after 6 weeks using nonresorbable Gore-Tex ${ }^{\circledR}$ membranes. ${ }^{8,9}$ We believe that in our study complete repair did not occur (40-50\%), not as a result of membrane collapse, but because the regenerative process was slower, which lead to failure of the technique at this level.

Group III (Lambone ${ }^{\circledR}$ membrane and Colloss $\left.{ }^{\circledR}\right)$ : The association of membrane and freeze-dried collagen improved bone regeneration with respect to the use of membrane alone. The differences in both the radiologic and histologic study were statistically significant differences at 3 weeks and at 6 weeks compared to the control group. These results, as suggested by other studies, demonstrated that the regenerative effects of biodegradable membranes can be potentiated by associating the membranes with a biomaterial defect filler. ${ }^{10,11}$ Our results coincide with the results of other authors who have postulated that freeze-dried collagen accelerates bone regeneration in the early phase (first 2 weeks). ${ }^{12}$ Radiographically, at 3 weeks the defects showed homogeneous levels of radiopacity, although with a certain lack of continuity with the adjacent bone. However, at 6 weeks we confirmed the repair of 80 to $100 \%$ of the defect, with high radiologic homogeneity and continuity.

Histologically, at 3 weeks bone formation was greater in peripheral areas, but at 6 weeks, there were no differences between the areas of the defect, indicating greater uniformity in the bone repair. There were even cases of total and homogeneous repair of the defect. When freeze-dried collagen is used alone, bone formation frequently advances 
Tabla 3. Media \pm Desviación estándar de la media de los resultados de los parámetros histológicos

\begin{tabular}{|c|c|c|c|c|}
\hline & Control & Membrana Lambone ${ }^{\circledR}$ & Membrana + Colloss ${ }^{\circledR}$ & Membrana + Novabone \\
\hline \multicolumn{5}{|l|}{ Madurez ósea } \\
\hline 3 semanas & $0,33 \pm 0,21$ & $1,83 \pm 0,31$ & $3,67 \pm 0,33$ & $0,33 \pm 0,21$ \\
\hline \multicolumn{5}{|l|}{ Médula ósea } \\
\hline 3 semanas & $0,17 \pm 0,17$ & $0,50 \pm 0,22$ & $1,67 \pm 0,33$ & $0,33 \pm 0,21$ \\
\hline 3 semanas & $0,17 \pm 0,17$ & $0,67 \pm 0,21$ & $2,83 \pm 0,31$ & $0,33 \pm 0,21$ \\
\hline 6 semanas & $0,33 \pm 0,21$ & $1,67 \pm 0,33$ & $4,50 \pm 0,22$ & $0,67 \pm 0,33$ \\
\hline \multicolumn{5}{|c|}{ Form. periférica } \\
\hline 3 semanas & $0 \pm 0$ & $0,33 \pm 0,21$ & $1,17 \pm 0,31$ & $0,17 \pm 0,17$ \\
\hline 6 semanas & $0,17 \pm 0,17$ & $0,67 \pm 0,33$ & $1,33 \pm 0,21$ & $0,33 \pm 0,21$ \\
\hline
\end{tabular}

Table 3. Mean \pm standard deviation of the mean results of histologic parameters

\begin{tabular}{|c|c|c|c|c|}
\hline & Control & Lambone ${ }^{\circledR}$ Membrane & Membrane + Colloss ${ }^{\circledR}$ & Membrane + Novabone \\
\hline \multicolumn{5}{|c|}{ Bone maturity } \\
\hline 3 weeks & $0,33 \pm 0,21$ & $1,83 \pm 0,31$ & $3,67 \pm 0,33$ & $0,33 \pm 0,21$ \\
\hline 6 weeks & $0,50 \pm 0,22$ & $2,83 \pm 0,31$ & $4,33 \pm 0,21$ & $0,83 \pm 0,31$ \\
\hline \multicolumn{5}{|c|}{ Bone marrow } \\
\hline 3 weeks & $0,17 \pm 0,17$ & $0,50 \pm 0,22$ & $1,67 \pm 0,33$ & $0,33 \pm 0,21$ \\
\hline 6 weeks & $0 \pm 0$ & $0,67 \pm 0,21$ & $1,83 \pm 0,31$ & $0,50 \pm 0,22$ \\
\hline \multicolumn{5}{|c|}{ Bone junction } \\
\hline 3 weeks & $0,17 \pm 0,17$ & $0,67 \pm 0,21$ & $2,83 \pm 0,31$ & $0,33 \pm 0,21$ \\
\hline 6 weeks & $0,33 \pm 0,21$ & $1,67 \pm 0,33$ & $4,50 \pm 0,22$ & $0,67 \pm 0,33$ \\
\hline \multicolumn{5}{|c|}{ Peripheral bone } \\
\hline 3 weeks & $0 \pm 0$ & $0,33 \pm 0,21$ & $1,17 \pm 0,31$ & $0,17 \pm 0,17$ \\
\hline 6 weeks & $0,17 \pm 0,17$ & $0,67 \pm 0,33$ & $1,33 \pm 0,21$ & $0,33 \pm 0,21$ \\
\hline
\end{tabular}

con cierta reacción inflamatoria a cuerpo extraño; además entre las partículas del biomaterial se encontraron espacios vacíos, posiblemente debido a la disolución de los gránulos y liberación de gel de sílice. ${ }^{16}$ La asociación de vidrio bioactivo con membrana de hueso desmineralizado interfiere en el proceso de regeneración ósea, ya que la formación de hueso en el defecto es incluso menor que cuando la membrana se utiliza de forma aislada. Por lo tanto, con este modelo experimental, no pueden demostrarse las propiedades osteoconductivas de los vidrios bioactivos.

\section{Bibliografía}

1. Taylor Gl. Reconstructive surgery of facial bones. Part 1: Free composite osteocutaneous grafts for jaw reconstruction. En: Stark RB (ed). Plastic Surgery of the Head and Neck. Churchill, Livingstone, 1987: 1109.

2. Vallet-Regí M, Ramila A, Padilla S, Muñoz B. Bioactive glasses as accelerators of apatite bioactivity. J Biomed Mater Res 2003;66:580-5.

3. Heiple KG, Chase SW, Herndon CH. A comparative study of the healing process following different types of bone transplantation. J Bone Joint Surg Am 1963; 45:1593-616. away from the area of the defect, which means that bone regeneration does not conform to the defect. ${ }^{13}$ The use of membranes prevents the dispersion of the biomaterial, increasing its concentration in the defect and enhancing the osteoinductive and osteoconductive stimulus. The membranes have the advantage of being biodegradable and not requiring a second surgical intervention for removal.

Histologic analysis of the specimens confirmed the radiographic and macroscopic results, yielding new data that suggested that combined treatment with freeze-dried collagen and resorbable demineralized bone membranes has advantages in the regeneration of critical mandibular defects.

Group IV (Lambone ${ }^{\circledR}$ membrane and NovaBone-C/M $\left.{ }^{\circledR}\right)$ : The bone regeneration achieved with membranes and bioactive glass did not differ significantly at any period in the evolution from the control group from a histologic vantage point. Interestingly, the radiologic study at 6 weeks showed statistically significant differences compared to the control group, which may contradict the histologic results. However, these results also have been found in other studies, such as the one by Dorea, ${ }^{14}$ in which femoral defects in cats repaired 
4. Majzoub Z, Cordioli G, Aramouni PK, Vigolo P, Piattelli A. Guided bone regeneration using demineralized laminar bone sheets versus GTAM membranes in the treatment of implant-associated defects. A clinical and histological study. Clin Oral Impl Res 1999;10:406-14.

5. Hämmerle CHF, Schmid J, Lang NP, Olah AJ. Temporal dynamics of healing in rabbit cranial defects using guided bone regeneration. / Oral Maxillofac Surg 1995;53:167-74.

6. Urist MR. Bone-Formation by autoinduction. Science 1965;150:893-9.

7. Kaban LB, Glowacki J. Induced osteogenesis in the repair of experimental mandibular defects in rats. J Dent Res 1981;60:1356-64.

8. Dahlin C, Linde A, Gottlow J, Nyman S. Healing of bone defects by guided tissue regeneration. Plast Reconstr Surg 1988;81:672-6.

9. Zellin G, Gritli-Linde A, Linde A. Healing of mandibular defects with differentes biodegradable and non-biodegradable membranes: an experimental study in rats. Biomaterials 1995;16:601-9.

10. Aaboe M, Pinholt EM, Hjorting-Hansen E. Healing of experimental created defects: a review. Br J Oral Maxillofac Surg 1995;33:312-8.

11. Mellonig JT, Nevins M, Sanchez R. Evaluation of a bioabsorbable physical barrier for guided bone regeneration. Part II. Material and a bone replacement graft. Int J Period Restor Dent 1998;18:129-37.

12. Kloss FR, Schlegel KA, Felszeghy E, Falk S, Wiltfang J. Applying an osteoinductive protein complex for regeneration of osseous defects. Mund Kiefer Gesichtschir 2004;8:12-7.

13. García Reija MF. Reparación de defectos críticos mandibulares con colágeno liofilizado en combinación con membranas reabsorbibles de colágeno. Tesis, Valladolid, Universidad de Valladolid, 2006.

14. Dorea HC, McLaughlin RM, Cantwell HD, Read R, Armbrust L, Pool R, et al. Evaluation of healing in feline femoral defects filled with cancellous autograft, cancellous allograft or Bioglass. Vet Comp Orthop Traumatol 2005;18:157-68.

15. Lasa C, Hollinger J, Drohan W, MacPhee M. Delivery of demineralized bone power fibrin sealant. Plast Reconstr Surg 1995;96:1409-18.

16. Shapoff CA, Alexander DC, Clark AE. Clinical use of a bioactive glass particulate in the treatment of human osseous defects. Comp Cont Ed Dentistry 1997; 18:352-63. with bioactive glass filler regenerated radiologically at 6 weeks without concordant histologic findings. For that reason, radiopacity per se should not be used as the only criterion for evaluating bone regeneration and should be correlated, as has been proposed, with the histologic findings. ${ }^{14}$ In fact, the apparent decrease in the size of the defect may be due to the precipitation of silica gel and the formation of calcium phosphate on the periphery of the defect, which is difficult to differentiate radiologically from host tissue. ${ }^{14}$ Histologically, the defects had not regenerated by 6 weeks; they were occupied by fibrous tissue and exhibited a foreign-body inflammatory reaction. There also were empty spaces between the particles of biomaterial, possibly due to the dissolution of granules and release of silica gel. ${ }^{16}$ The association of bioactive glass with demineralized bone membrane appeared to interfere with the process of bone regeneration, since there was less bone formation in the defect than when the membrane was used alone. Therefore, this experimental model did not demonstrate the osteoconductive properties of bioactive glass. 